\title{
Retraction Note: Open reduction and closed reduction internal fixation in treatment of femoral neck fractures: a meta-analysis
}

Weiguo Wang ${ }^{1,2}$, Junjie Wei ${ }^{3}$, Zhanwang $\mathrm{Xu}^{4^{*}}$, Wenkun Zhuo ${ }^{1}$, Yuan Zhang ${ }^{1}$, Hui Rong ${ }^{1}$, Xuecheng Cao ${ }^{1}$ and Pingshan Wang ${ }^{1}$

\section{Retraction}

The Publisher and Editor regretfully retract this article [1] because the peer-review process was inappropriately influenced and compromised. As a result, the scientific integrity of the article cannot be guaranteed. A systematic and detailed investigation suggests that a third party was involved in supplying fabricated details of potential peer reviewers for a large number of manuscripts submitted to different journals. In accordance with recommendations from COPE we have retracted all affected published articles, including this one. It was not possible to determine beyond doubt that the authors of this particular article were aware of any third party attempts to manipulate peer review of their manuscript.

\section{Author details \\ ${ }^{1}$ Department of Orthopaedic Surgery, General Hospital of Jinan Military Command, 250031 Jinan, China. ${ }^{2}$ Research on 2013 stage doctoral student of TCM Orthopaedics, Shandong University of Traditional Chinese Medicine, Jinan, China. ${ }^{3}$ Outpatient Department, General Hospital of Jinan Military Command, 250031 Jinan, China. ${ }^{4}$ Department of Orthopaedics, The First Affiliated Hospital of Shandong University of Traditional Chinese Medicine, NO.16369, Jingshi Road, 250014 Jinan, China.}

Received: 23 January 2015 Accepted: 4 March 2015

Published online: 26 March 2015

\section{Reference}

1. Wang W, Wei J, Xu Z, Zhuo W, Zhang Y, Rong H, Cao X, Wang P. Open reduction and closed reduction internal fixation in treatment of femoral neck fractures: a meta-analysis. BMC Musculoskeletal Disorders. 2014;15:167.

\footnotetext{
* Correspondence: zhanwangxu@hotmail.com

${ }^{4}$ Department of Orthopaedics, The First Affiliated Hospital of Shandong University of Traditional Chinese Medicine, NO.16369, Jingshi Road, 250014 Jinan, China
}

\section{Submit your next manuscript to BioMed Central and take full advantage of: \\ - Convenient online submission \\ - Thorough peer review \\ - No space constraints or color figure charges \\ - Immediate publication on acceptance \\ - Inclusion in PubMed, CAS, Scopus and Google Scholar \\ - Research which is freely available for redistribution

